\title{
Introduktion: Tænketanke i de nordiske lande
}

\author{
Mark Blach-Ørsten \& Nete Nørgaard Kristensen
}

Dette temanummer sætter fokus på tænketanke i de nordiske lande. Internationalt, især i USA, har forskningen længe interesseret sig for tænketanke og deres forsøg på at opnå indflydelse ved at påvirke den politiske og offentlige debat, mens europæisk forskning på området stadig er begrænset. Inden for de seneste ti år har der imidlertid været en vækst i antallet af tænketanke i Europa - en udvikling, der også kendetegner de nordiske lande, hvor Sverige har det højeste antal tænketanke, mens antallet i Danmark, Finland og Norge er mindre, men stigende. Forskningen i tænketanke i de nordiske er dog stort set fraværende (fx Bjerke 2015). Disse forhold - på den ene side et stigende antal tænketanke i Norden og på den anden side en manglende nordisk forskningsinteresse for fænomenet - har motiveret dette særnummer.

Selvom tænketanke kan variere i type, størrelse og formål, har de fleste tænketanke i stigende grad fokus på at opnå indflydelse på politiske og offentlige dagsordner via synlighed i nyhedsmedier. Det peger på en tredje årsag til, at det nordiske perspektiv kan være særlig interessant. Internationalt betragtes de nordiske lande nemlig både politisk og mediesystemisk som mere lig hinanden end forskellige i lyset af forankringen i den nordiske velfærdsmodel (fx Edling et al. 2006, Petetersen 2011) og den demokratisk korporative mediemodel (fx Hallin \& Mancini 2004, Syversen et al. 2014). Studier peger dog også på forskelle inden for de nordiske lande, fx i deres politiske kommunikation (Allern \& Ørsten 2011; Strömbäck et al. 2008). Netop derfor er det relevant at undersøge, hvilke ligheder og forskelle der er i tænketankenes indtog i de nordiske lande, herunder deres størrelse, antal og gennemslagskraft i medierne.

Fire af de fem artikler i dette nummer udspringer således også af et fælles nordisk forskningsnetværk, som i perioden 2012 til 2015 har sat fokus på tænketanke og deres synlighed i nordiske nyhedsmedier. Baseret på teorier om medialiering af politik samt de-korporatisering af det politiske system, argumenterer de fire artikler på forskellig vis for, at der er sket forandringer i de institutionelle rammer for produktionen af politiske ideer på tværs af og inden for de enkelte nordiske lande, og at disse forandringer er nogle af årsagerne til den seneste stigning i antallet af tænketanke. Artiklernes analyser baserer sig derfor, overordet set, også på det samme empiriske design i form af kvantitative indholdsanalyser, baseret på en fælles kodebog, med fokus på årene 2006 og 2013 og repræsentationen af centrale nationale tænketanke af forskellig politisk observans i 
dagsordensættende aviser i Danmark, Sverige, Norge og Finland. Artiklernes analyser betoner dog forskellige dimensioner af denne medierepræsentation og er først og fremmest nationalt fokuseret. Netop på grund af fraværet af empirisk forskning på området i Norden, har målet været at etablere nationale baseline-studier, mens det komparative perspektiv manifesters på tværs af artiklerne.

Fordi tænketanke er et inklusivt begreb, der kan dække over mange, forholdsvis forskelligt organiserede aktører, adresserer alle artiklerne mere eller mindre detaljeret, hvordan tænketanke kan defineres - og hvordan disse definitioner operationaliseres i de enkelte artiklers studier. Temanummerets første artikel, af Jesper Dahl Kelstrup, som er skrevet uden for det nordiske forskningsnetværk om tænketanke, har fx et overordnet fokus på at diskutere, definere og afgrænse, hvad en tænketank er. Kelstrup foreslår at se tænketanke som "permanente organisationer, der hævder en grad af uafhængighed og søger politisk indflydelse ved at mobilisere ekspertviden.” Udover interessen for teoretisk at definere, hvad en tænketank er i både USA og Danmark, giver Kelstrups artikel et overordnet billede af den kamp om nyhedsmediernes opmærksomhed, der udkæmpes mellem tænketanke som nye politiske aktører i den politiske debat og traditionelle korporative aktører, navnlig interesseorganisationer.

Den næste artikel, af Mark Blach-Ørsten \& Nete Nørgaard Kristensen, ser på medialiseringen af tænketanke i syv danske aviser og på tænketankenes netværksrelationer i de korporative netværk, som kan ses som den klassiske vej til politisk indflydelse i det danske samfund. Baseret på de danske data fra den nordiske indholdsanalyse, peger artiklen på stigende synlighed af tænketanke i medieoffentligheden samt en klar tendens til at lade tænketanke optræde som uvildige eksperter frem for som partskilder. Den supplerende netværksanalyse viser dog samtidig, at de korporative netværk langt fra er smuldret væk. Hvor den liberale tænketank CEPOS har den største andel af mediedækningen, er den socialdemokratisk forbundne tænketank AE-Rådet tættest repræsenteret $\mathrm{i}$ forskellige netværk uden for medierne.

Paul Bjerkes artikel ser på tænketanke i Norge baseret på såvel indholdsanalyse som interview med relevante aktører. Artiklen konkluderer blandt andet, at de undersøgte tænketanke er forholdsvis små organisationer med relativt få ansatte, men også organisationer, der har en stærk gennemslagskraft i de norske nyhedsmedier. Her opnår de gerne en positiv omtale, men typisk uden en tydelig marketing af deres ideologiske ståsted. Det peger, ifølge artiklen, på de gensidige interesser, nyhedsmedier og tænketanke har $\mathrm{i}$ henholdsvis professionelt kommentarstof af nyhedsværdi og en offentlig arena til fremsættelse af ideer, udspil og argumenter. 
Den fjerde artikel, skrevet af Sigurd Allern og Ester Pollack, fokuserer især på Sveriges ældste og mest kendte tænketank, den neoliberale tænketank Timbro, der blev grundlagt i 1978. Som reaktion på Timbros succes har Sverige i de senere år set en vækst i tænketanke, både nogle med et neoliberalt udgangspunkt og tænketanke, der udspringer fra andre dele af den politiske højre-venstre skala. På trods af væksten i antallet af tænketanke viser indholdsanalysen dog, at Timbro har den stærkeste gennemslagskraft i de svenske nyhedsmedier.

Temanummerets sidste artikel, af Lotta Lounasmeri, fokuserer på tænketanke i Finland. Her ser både det politiske landskab, nyhedsmedierne og antallet af tænketanke lidt anerledes ud sammenlignet med de andre nordiske lande. Artiklen fokuserer således på de særlige finske forhold og konkluderer blandt andet, at tænketanke ikke er slået igennem i den finske offentlighed på samme måde, som det ser ud til at være tilfældet i de øvrige nordiske lande. Kun en tænketank af betydning, EVA, er for alvor synlig i de finske medier.

\section{Referencer:}

Allern, S \& M Blach-Ørsten (2011) 'The News Media as a Political Institution: A Scandinavian Perspective', Journalism Studies 12(1): 92-105

Bjerke, P. (2015) Tankesmier på norsk: hjemmelaget import, i Ihlen, Ø., Skoberbø, E. \& Allern, S., Makt, medier og politikk. Oslo: Universitetsforlaget.

Edling, N. et al. 2006. The Nordic Model of Welfare, Museum Tusculanum

Hallin, D.C. and P. Mancini (2004) Comparing Media Systems. Cambridge University Press.

Petersen, K. (2011) 'National, Nordic and Trans-Nordic. Transnational Perspectives on the History of the Nordic Welfare State.' I K. Petersen et al. Beyond welfare state models

Strömbäck, J. et al. (2008) Political Communication in the Nordic Countries. NORDICOM

Syvertsen, T. et al. (2014) The Media Welfare State: Nordic Media in the Digital Area, Michigan: University of Michigan Press 